\title{
Quality of life in chronic pain is more associated with beliefs about pain, than with pain intensity
}

Citation for published version (APA):

Lamé, I. E., Peters, M. L., Vlaeyen, J. W. S., van Kleef, M., \& Patijn, J. (2005). Quality of life in chronic pain is more associated with beliefs about pain, than with pain intensity. European Journal of Pain, 9(1), 15-24. https://doi.org/10.1016/j.ejpain.2004.02.006

Document status and date:

Published: 01/01/2005

DOI:

10.1016/j.ejpain.2004.02.006

Document Version:

Publisher's PDF, also known as Version of record

Document license:

Taverne

\section{Please check the document version of this publication:}

- A submitted manuscript is the version of the article upon submission and before peer-review. There can be important differences between the submitted version and the official published version of record.

People interested in the research are advised to contact the author for the final version of the publication, or visit the DOI to the publisher's website.

- The final author version and the galley proof are versions of the publication after peer review.

- The final published version features the final layout of the paper including the volume, issue and page numbers.

Link to publication

\footnotetext{
General rights rights.

- You may freely distribute the URL identifying the publication in the public portal. please follow below link for the End User Agreement:

www.umlib.nl/taverne-license

Take down policy

If you believe that this document breaches copyright please contact us at:

repository@maastrichtuniversity.nl

providing details and we will investigate your claim.
}

Copyright and moral rights for the publications made accessible in the public portal are retained by the authors and/or other copyright owners and it is a condition of accessing publications that users recognise and abide by the legal requirements associated with these

- Users may download and print one copy of any publication from the public portal for the purpose of private study or research.

- You may not further distribute the material or use it for any profit-making activity or commercial gain

If the publication is distributed under the terms of Article $25 \mathrm{fa}$ of the Dutch Copyright Act, indicated by the "Taverne" license above, 


\title{
Quality of life in chronic pain is more associated with beliefs about pain, than with pain intensity
}

\author{
Inge E. Lamé ${ }^{\mathrm{a}, *}$, Madelon L. Peters ${ }^{\mathrm{b}}$, Johan W.S. Vlaeyen ${ }^{\mathrm{b}}$, \\ Maarten v. Kleef ${ }^{\text {a }}$, Jacob Patijn ${ }^{\text {a }}$ \\ a Pain Management and Research Centre, University Hospital Maastricht, P.O. Box 5800, 6202 AZ Maastricht, The Netherlands \\ ${ }^{\mathrm{b}}$ Department of Medical, Clinical and Experimental Psychology, University Maastricht, Postbus 616, 6200 MD Maastricht, The Netherlands
}

Received 19 August 2003; accepted 6 February 2004

Available online 12 March 2004

\begin{abstract}
Objectives. The objectives of this study were to investigate pain cognitions and quality of life of chronic pain patients referred to a multi-disciplinary university pain management clinic and to search for predictors of quality of life.

Methods. A heterogeneous group of 1208 chronic pain patients referred to the Maastricht university hospital pain clinic participated in this cross-sectional study. At the initial assessment, all patients completed a set of questionnaires on demographic variables, cause, location, pain intensity (McGill pain questionnaire, MPQ), pain coping and beliefs (pain coping and cognition list, PCCL), pain catastrophising (pain catastrophising scale, PCS) and eight dimensions of quality of life (Rand-36).

Results. The results showed that the present sample of heterogeneous pain patients reported low quality of life on each domain and significantly lower scores than has been found in previous studies with other Dutch chronic pain populations. Patients with low back pain and multiple pain localisations experienced most functional limitations. Women reported more pain, more catastrophising thoughts about pain, more disability and lower vitality and general health. When tested in a multiple regression analysis, pain catastrophising turned out to be the single most important predictor of quality of life. Especially social functioning, vitality, mental health and general health are significantly associated with pain catastrophising.

Conclusions. Patients from a multi-disciplinary university pain clinic experience strikingly low quality of life, whereby low back pain patients and patients with multiple pain localisations have the lowest quality of life. Pain catastrophising showed the strongest association with quality of life, and stronger than pain intensity.

(C) 2004 Published by Elsevier Ltd on behalf of European Federation of Chapters of the International Association for the Study of Pain.
\end{abstract}

Keywords: Chronic pain; Quality of life; Rand-36; Catastrophising

\section{Introduction}

It is generally accepted that chronic pain has a negative impact on quality of life (Kempen et al., 1997; Schlenk et al., 1998; Stewart et al., 1989). Chronic pain has negative consequences for general health (Becker et al., 1997) and for social and psychological well-being (Gureje et al., 1998). Nowadays, psycho-diagnostic procedures are considered indispensable tools in the diagnosis and management of chronic non-malignant

\footnotetext{
${ }^{*}$ Corresponding author. Tel.: +31-433875435; fax: +31-433875457.

E-mail address: ila@sane.azm.nl (I.E. Lamé).
}

pain. The prevailing model of chronic pain is based on a bio-psycho-social approach, in which depression, pain related fear and catastrophising play a prominent role. Chronic pain is related to high levels of anxiety, depression, social and occupational dysfunction (Crombez et al., 1999b; Romano and Turner, 1985; Sullivan and Loeser, 1992; Turk and Okifuji, 1996). Fear-avoidance models have been developed to describe this relation (Lethem et al., 1983; Vlaeyen and Linton, 2000; Vlaeyen et al., 1995b). These models assume that pain catastrophising promotes fear of movement/(re)injury. The latter, in turn, leads to avoidance behaviour, disuse, disability and depression. 
Pain catastrophising has been broadly defined as an exaggerated negative orientation toward pain stimuli and pain experience (Sullivan et al., 1995). There is increasing evidence for the role of catastrophising and fear of movement in the transition of acute to chronic pain, whereby the importance of early detection by means of screening and early intervention is endorsed (Buer and Linton, 2002; Linton, 2002). The relation between pain catastrophising, pain-related fear and disability is mainly described in the literature in low back pain patients (Buer and Linton, 2002; Crombez et al., 1999b; Hout van den et al., 2001; Sieben et al., 2002; Vlaeyen et al., 1995a,b), although some researchers have found evidence in other diagnosis groups as well (Keefe et al., 1989, 2000; Sullivan and Karlsson, 1998).

A different aspect of pain catastrophising and pain related fear concerns the potential negative influence on the medical treatment of chronic pain patients. Samwel et al. (2000) found a negative correlation between pain catastrophising and the effect of a radiofrequency lesion of the dorsal root ganglion in a population with cervical brachialgia. They hypothesised that a psychological treatment strategy focusing on decreasing the level of catastrophising, could mediate a positive effect of medical treatment. If indeed psycho-diagnostic procedures can provide a better insight into planned treatment strategies for the chronic pain patient (Morley et al., 1999), it is important that these psychological factors are diagnosed in an early stage. General use of a combination of quality of life and psychological measuring instruments as screening would be a first step to obtain a better insight into the psychological starting point of a chronic pain population.

The first aim of this study is to present descriptive data of quality of life for patients presenting with heterogeneous chronic pain complaints at a university hospital pain management clinic. In order to place these data in proper perspective, comparisons with previous Dutch studies on other chronic pain populations and with healthy controls are made. Moreover, quality of life is presented for different pain locations and for males and females separately. The second aim of the study was to search for predictors of quality of life. The role of pain cognitions and pain coping in explaining the various domains of quality of life was studied, controlling for pain intensity and demographic variables.

\section{Materials and methods}

\subsection{Patients}

A cross-sectional study was performed in a population of the outpatient's clinic for Pain and Pain management of the University Hospital Maastricht, The Netherlands. This population is a heterogeneous group of chronic pain patients with different localisations of pain, such as low back pain, neck pain, shoulder pain, different forms of headache, complex regional pain syndrome type I and II (CRPS I and II), neuropathic pain syndrome, central pain and abdominal pain. Questionnaires were mailed to every new non-malignant pain patient between February 2000 and March 2002 $(n=1333)$. Patients had to return the completed questionnaire before their first appointment with the physician. Finally $91 \%(n=1208)$ returned the questionnaire and were included in the study.

\subsection{Measuring instruments}

The screening questionnaire consisted of two parts. The first part asked for demographic information and information about cause, localisation and duration of pain. The second part consisted of four standard measuring instruments: Rand-36, pain coping and cognition list (PCCL), pain catastrophising scale (PCS) and the McGill pain questionnaire (MPQ).

\subsubsection{Rand-36}

This instrument was developed during the Medical Outcome Studies of the Rand Corporation and measures general health and quality of life (Van der Zee et al., 1993). The items of the Dutch version of the Rand-36 are identical to the Dutch translation of the SF-36 (Aaronson et al., 1992). It contains 36 items, measuring eight aspects of health (domains): physical functioning $(\mathrm{PF})$, social functioning $(\mathrm{SF})$, role limitations physical (RP), role limitations emotional (RE), mental health $(\mathrm{MH})$, vitality $(\mathrm{VI})$, bodily pain $(\mathrm{BP})$ and general health perception $(\mathrm{GH})$. Perceived health change over the last year is measured with one item. All raw scale scores are linearly converted to a $0-100$ scale, with higher scores indicating higher levels of functioning or well being (Aaronson et al., 1998). Psychometric properties of the Dutch version of the Rand-36 were found adequate (Aaronson et al., 1998; Essink Bot et al., 1997; Van der Zee et al., 1993, 1996).

\subsection{2. $P C C L$}

The pain coping and cognition list was developed by the Pain Management and Research Centre (PKC) of the University Hospital, Maastricht, The Netherlands (Stomp-van den Berg et al., 2001). It is constructed from the Pain Cognition List (Vlaeyen et al., 1990), Locus of Pain Control questionnaire (Engstrom, 1983); Dutch version: (Kuile ter et al., 1993) and the Coping Strategies Questionnaire (Spinhoven et al., 1994). The PCCL includes all the unique information of the original lists and consists of 42 items, subdivided in four scales: pain catastrophising (higher scores denote a higher degree of catastrophising), pain coping (lower scores denote a lower degree of pain coping), internal pain control 
(lower scores denote less internal pain control) and external pain control (higher scores denote less external pain control, i.e., more health control by others). Stomp-van den Berg et al. (2001) found support for the internal consistency and construct validity of the PCCL.

\subsubsection{PCS}

This instrument measures the degree of catastrophic thoughts about pain (Crombez and Vlaeyen, 1996; Sullivan et al., 1995). The PCS is a 13-item 5-point scale, mostly used as a total score. Sullivan et al. (1995) proposed three dimensions of pain catastrophising: rumination, magnification and helplessness. Beside total score values, also subscale scores can be measured. Higher scores denote a higher degree of catastrophising. Psychometric properties of the PCS appeared adequate in previous studies (Crombez et al., 1998; Crombez et al., 1999b; Van Damme et al., 2000; Vlaeyen et al., 1990). The PCS has been shown to have good reliability and validity in a clinical population (Crombez et al., 1998) and in a student population (Crombez et al., 1999b).

\subsection{4. $M P Q$}

The MPQ measures three dimensions of pain experience: the sensory, affective and evaluative dimensions of pain. The instrument consists of an adjective list, divided into twelve sensory, five affective and three evaluative subclasses. It groups various pain adjectives (descriptions) according to their pain quality and ranks the adjectives of a certain quality according to their intensity. Two major measures are distilled from the adjective list: The number of words chosen (NWC) and the pain-rating index (PRI). The present study only uses the PRI total score. The PRI adds the rankings of all words chosen. Higher scores denote more pain. The psychometric properties of the Dutch language version of the MPQ, constructed by (Verkes et al., 1989), were found to be encouraging.

\subsection{Statistical analysis}

To calculate differences between the population characteristics, the psychological characteristics and differences with other populations, a Student's $t$ test was employed. The assumption of equal variance between the different sites of pain was tested by Levene's test for equality of variance, after which differences between the groups were tested with ANOVA. More conservative post hoc tests (Bonferroni and LSD) were employed to specify the differences. The predictors of quality of life were calculated with a hierarchical stepwise regression analyses, in which the demographic variables (gender, age, education) and pain intensity were entered in the first step and the predictors of interest (four PCCL subscale scores: catastrophising, pain coping, internal and external pain control) were entered in the second step. For every domain of quality of life the additional variance explained by significant predictors was shown in the final model, after controlling for demographic variables and pain intensity. To exclude the influence of multicollinearity, we calculated the VIF value for every independent variable. The variable was included if VIF $<3$.

\section{Results}

\subsection{Population characteristics}

The study population characteristics are summarised in Table 1. The population had a mean age of 49.9 years (SD 14.7), 51.5\% had a relatively low education (lower vocational education or less) and $62 \%$ of the patients were female. The localisations of the pain were diverse and classified into five pain clusters: headache $(2.4 \%)$, including all different appearances of headache, such as migraine, tension type of headache, cervicogenic headache and cluster headache; neck pain and/or brachialgia $(23.3 \%)$, including arm pain and combinations of arm and neck pain; back pain and/or sciatica $(27.9 \%)$, including leg pain and combinations of leg and back pain; other pain, such as CRPS I en II, neuropathic pain syndrome, trigeminus neuralgia, fibromyalgia and rheumatoid arthritis (15.7\%) and finally a cluster with all possible combinations of the first four clusters (multiple pain localisations) (30.1\%). In all clusters there was an overrepresentation of females (headache (55.2\%), neck pain (59.5\%), back pain (59.3\%), other pain (66.6) and multiple pain locations $(65.7 \%))$. There were no differences between the five clusters in age, gender or education.

\subsection{Descriptive data on quality of life}

\subsubsection{Quality of life in relation to pain location and demographic variables}

The Rand-36 mean domain scores are summarised in Table 2. Due to missing values in Rand-36 item scores a variable number of patients were excluded for the eight domains. Differences between the pain clusters were found on all domains with the exception of role limitations emotional. Patients with back pain, other pain and

Table 1

Population characteristics

\begin{tabular}{lll}
\hline & Male & Female \\
\hline$N(\%)$ & $461(38)$ & $743(62)$ \\
Age (mean(SD) & $50,2(13,5)$ & $49,6(15,3)$ \\
[range]) & {$[15-94]$} & {$[14-88]$} \\
\hline
\end{tabular}

$\mathrm{SD}$, standard deviation; range, minimum age-maximum age. 
Table 2

Quality of life domain total mean scores and mean scores of the different pain clusters

\begin{tabular}{|c|c|c|c|c|c|c|c|}
\hline & $\begin{array}{l}\text { Number of } \\
\text { patients }(n)\end{array}$ & $\begin{array}{l}\text { Total score } \\
\text { (SD) }\end{array}$ & $\begin{array}{l}\text { Headache } \\
\text { (1) }\end{array}$ & $\begin{array}{l}\text { Neck pain } \\
\text { (2) }\end{array}$ & $\begin{array}{l}\text { Back pain } \\
\text { (3) }\end{array}$ & $\begin{array}{l}\text { Other pain } \\
\text { (4) }\end{array}$ & $\begin{array}{l}\text { Multiple pain } \\
\text { localisations (5) }\end{array}$ \\
\hline \multicolumn{8}{|l|}{ Rand-36 } \\
\hline Physical functioning & 1119 & $41.3(26.3)$ & $66.2(27.3)^{\mathrm{a} 3,4,5}$ & $55.1(23.1)^{\mathrm{a} 3,5}$ & $31.0(21.1)^{\mathrm{a} 1,2,4}$ & $49.8(31.0)^{\mathrm{a} 1,3,5}$ & $34.0(23.0)^{\mathrm{a} 1,2,4}$ \\
\hline Social functioning & 1191 & $39.9(27.0)$ & $41.0(27.3)$ & $43.7(27.7)^{\mathrm{a} 5}$ & $38.3(27.2)$ & $43.7(26.8)$ & $36.4(25.8)^{\mathrm{a} 2}$ \\
\hline $\begin{array}{l}\text { Role limitations } \\
\text { physical }\end{array}$ & 1104 & $9.7(24.3)$ & $8.9(22.8)$ & $9.9(25.0)$ & $8.6(22.5)^{\mathrm{a} 4}$ & $16.7(31.3)^{\mathrm{a} 3,5}$ & $7.4(20.8)^{\mathrm{a} 4}$ \\
\hline $\begin{array}{c}\text { Role limitations } \\
\text { emotional }\end{array}$ & 1061 & $46.6(46.1)$ & $60.7(46.3)$ & $47.0(46.4)$ & $47.8(45.9)$ & $49.4(47.0)$ & $42.5(45.5)$ \\
\hline Mental health & 1125 & $56.7(22.6)$ & $56.9(18.9)$ & 57.7 (22.9) & $60.1(22.2)^{\mathrm{a} 5}$ & $57.6(21.4)$ & $52.4(23.0)^{\mathrm{a} 3}$ \\
\hline Vitality & 1142 & $39.8(20.4)$ & $40.9(19.3)$ & $43.5(21.1)^{\mathrm{a}} 5$ & $41.4(19.2)^{\mathrm{a} 5}$ & $40.6(21.2)$ & $35.2(19.8)^{\mathrm{a} 2,3}$ \\
\hline Bodily pain & 1185 & $24.6(17.9)$ & $24.6(17.0)$ & $24.9(18.3)^{\mathrm{a} 4}$ & $22.7(17.3)^{\mathrm{a} 4}$ & $30.2(19.5)^{\mathrm{a} 2,3,5}$ & $23.2(16.5)^{\mathrm{a} 4}$ \\
\hline General health & 1109 & $44.7(21.4)$ & $53.7(21.6)^{\mathrm{a} 5}$ & $48.8(20.8)^{\mathrm{a} 5}$ & $47.3(21.7)^{\mathrm{a} 5}$ & $46.8(21.9)^{\mathrm{a} 5}$ & $37.4(19.7)^{\mathrm{a} 1,2,3,4}$ \\
\hline
\end{tabular}

${ }^{\mathrm{a}}$ Significant difference $(p<0.05)$ with pain clusters corresponding to the numbers in superscript.

Table 3

Gender characteristics of quality of life domains

\begin{tabular}{|c|c|c|c|c|c|}
\hline & Male (SD) & Female (SD) & $t$ & $\mathrm{df}$ & $p$ value \\
\hline \multicolumn{6}{|l|}{ Rand-36 } \\
\hline Physical functioning & $44.0(26.2)$ & $39.6(26.2)$ & 2.714 & 1116 & 0.007 \\
\hline Social functioning & $41.4(27.0)$ & $39.0(27.0)$ & 1.47 & 1188 & 0.142 \\
\hline Role limitations physical & $12.3(26.7)$ & $8.2(22.5)$ & 2.606 & 1101 & 0.009 \\
\hline Role limitations emotional & $47.2(45.6)$ & $46.3(46.5)$ & 0.298 & 1059 & 0.765 \\
\hline Mental health & $57.7(21.8)$ & $56.1(23.0)$ & 1.143 & 1122 & 0.253 \\
\hline Vitality & $42.5(20.4)$ & $38.1(20.2)$ & 3.631 & 1138 & $<0.0001$ \\
\hline Bodily pain & $27.0(18.4)$ & $23.1(17.3)$ & 3.629 & 1181 & $<0.0001$ \\
\hline General health & $46.4(21.0)$ & $43.6(21.7)$ & 2.108 & 1106 & 0.035 \\
\hline
\end{tabular}

Mean scale scores, standard deviations (SD) and degrees of freedom (df).

multiple pain locations experience more functional limitations (physical functioning and role limitations physical) than the other clusters. In addition, patients with multiple pain localisations scored significantly lower on mental health, vitality and general health. Patients with other pain showed significantly lower scores on bodily pain than the other clusters. Gender differences were found for physical functioning, role limitations physical, vitality, bodily pain and general health, whereby women reported lower scores than men (Table 3).

\subsubsection{Quality of life compared to other patient popula- tions}

Fig. 1 shows quality of life domains obtained in the present study, compared to the results found in other chronic pain populations in the Netherlands, using the Dutch version of the SF-36, i.e. migraine and cancer pain (Aaronson et al., 1998). Moreover data of a healthy reference population, using the Rand-36, is presented (Van der Zee et al., 1993). This reference population was derived from a random sample survey from the population register of Emmen $(N=1063)$, a city in the eastern part of the Netherlands. A group of 292 patients without chronic diseases was taken from this sample and used as a healthy reference population (Van der Zee et al., 1993). The population with migraine $(N=423$, 40.4 years (SD 12.8) [16-88], 84\% women) consisted of patients who had been identified in an earlier study as migraine sufferers conform to the International Headache Society (Essink Bot et al., 1997). The population with cancer pain $(N=485,57.3$ years (SD 12.1) [22-86], $58 \%$ women) was a heterogeneous sample of cancer patients, primarily with breast, colorectal or lung cancer, recruited from the outpatient clinics of the Antoni van Leeuwenhoek Hospital, a cancer treatment centre located in Amsterdam (Aaronson et al., 1998). Another Dutch investigation, using the Dutch version of the SF36 , (not shown in the figure) concerned a chronic pain population presenting themselves to the general practitioner $(N=305,48.6$ years (SD 12.7) [19-87], 71.5\% women) (Verhaak et al., 2000). The authors presented only mean domain scores of physical functioning, role limitations physical, mental health and vitality. We tested the Rand-36 scores on all domains obtained from our patient group against each of the four other Dutch samples. As can be seen from Table 4, the chronic pain patient from the multi-disciplinary university pain clinic 


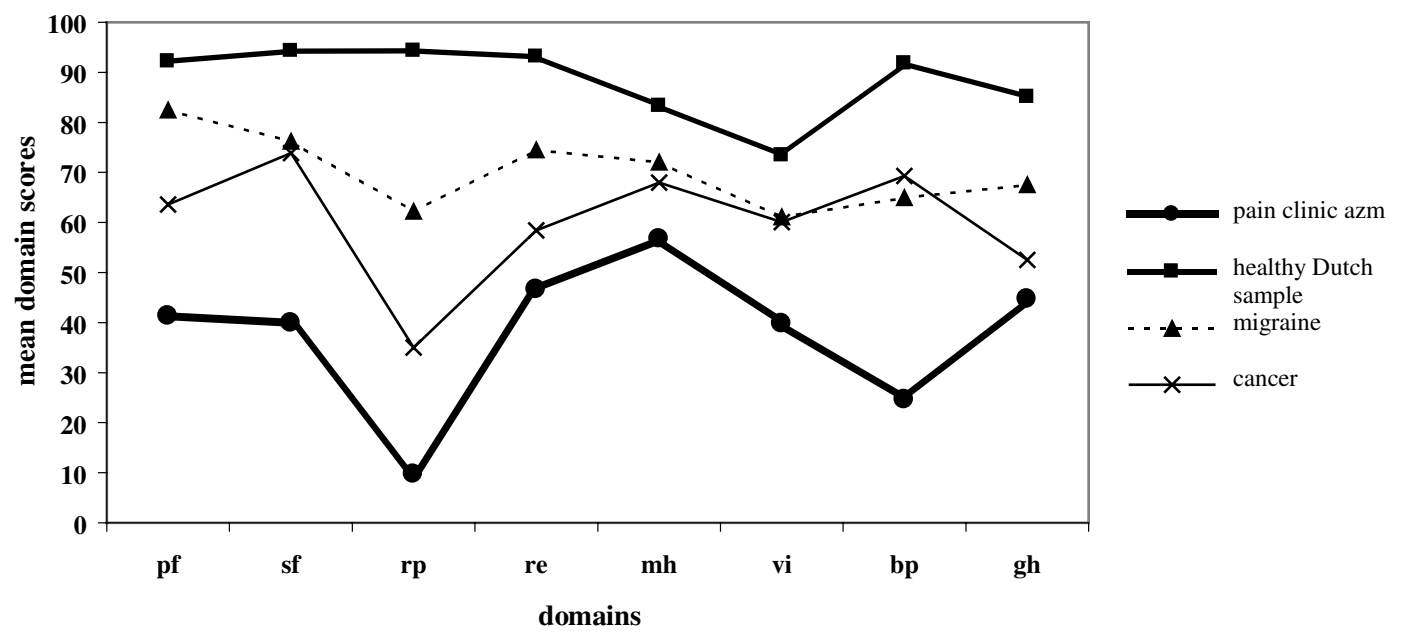

Fig. 1. Quality of life of the population of a pain clinic compared with other patient populations and a healthy Dutch reference group (pf, physical functioning; sf, social functioning; rp, role limitations physical; re, role limitations emotional; mh, mental health; vi, vitality; bp, bodily pain; gh, general health).

scored significant lower on all domains than each of the other groups.

\section{Prediction of quality of life}

Table 5 summarizes the final regression models showing the significant predictors that were retained after hierarchical stepwise regression analyses. In the first step, demographic variables and pain intensity were entered. Age and education showed a substantial (i.e. $>0.10$ ) association with physical functioning only. It is notable, that gender was not significantly related (or only very weakly) to any of the quality of life domains when other predictors were taken into account. Pain intensity showed a significant negative association with each of the quality of life domains, although this association was not very strong (beta values between 0.06 and 0.20). Step 2 shows the additional variance explained by pain coping and cognitions after controlling for the demographic variables and pain. Only significant predictors were retained in the model. As can be seen from Table 5, without exception, pain catastrophising was most strongly related to each of the quality of life domains, and more strongly than pain intensity and the demographic variables. Patients with high catastrophising cognitions had a lower quality of life than patients who were less catastrophising. Especially social func-

\footnotetext{
${ }^{1}$ Note that in this study pain catastrophising was also measured with the Pain Catastrophising Scale (PCS) (Sullivan et al., 1995); Dutch version: (Crombez and Vlaeyen, 1996). Both scales (catastrophising PCCL and catastrophising PCS) correlated 0.64 and to avoid multicollinearity only one scale was selected. Because other subscales of the PCCL were used as well, the decision was made to use the scale catastrophising from the PCCL. When the PCS was used instead, similar results were found.
}

tioning, vitality, mental health and general health demonstrated very prominent associations with catastrophising. ${ }^{1}$ Low internal pain control was further associated with lower emotional role functioning, less mental health and less general health, but with higher scores on quality of life in relation to bodily pain. External pain control and pain coping showed only weak and inconsistent relations to the various quality of life domains.

\section{Discussion}

The primary aim of this study was to provide descriptive data on quality of life in a heterogeneous group of chronic pain patients from a multi-disciplinary university pain clinic in the Netherlands. Moreover the influence of demographic variables, pain intensity and pain cognition on the various domains of quality of life was explored. Notable results were found for all quality of life domains. The chronic pain patient from the multi-disciplinary university pain clinic scored significant lower on all domains than each of the other Dutch reference groups, including a heterogeneous sample of cancer patients with metastases and a heterogeneous chronic pain population presenting themselves to the general practitioner (Aaronson et al., 1998; Verhaak et al., 2000). When the different pain clusters are taken into account, particularly patients with low back pain and multiple pain localisations have lower scores. Kempen et al. (1997) noted similar results in an elderly Dutch population. In this study eight chronic medical conditions were identified (asth$\mathrm{ma} /$ chronic bronchitis, heart condition, hypertension, diabetes mellitus, back problems for at least three months, rheumatoid arthritis/other joint complaints, 
Table 4

Quality of life of the population of the pain clinic compared to other Dutch populations

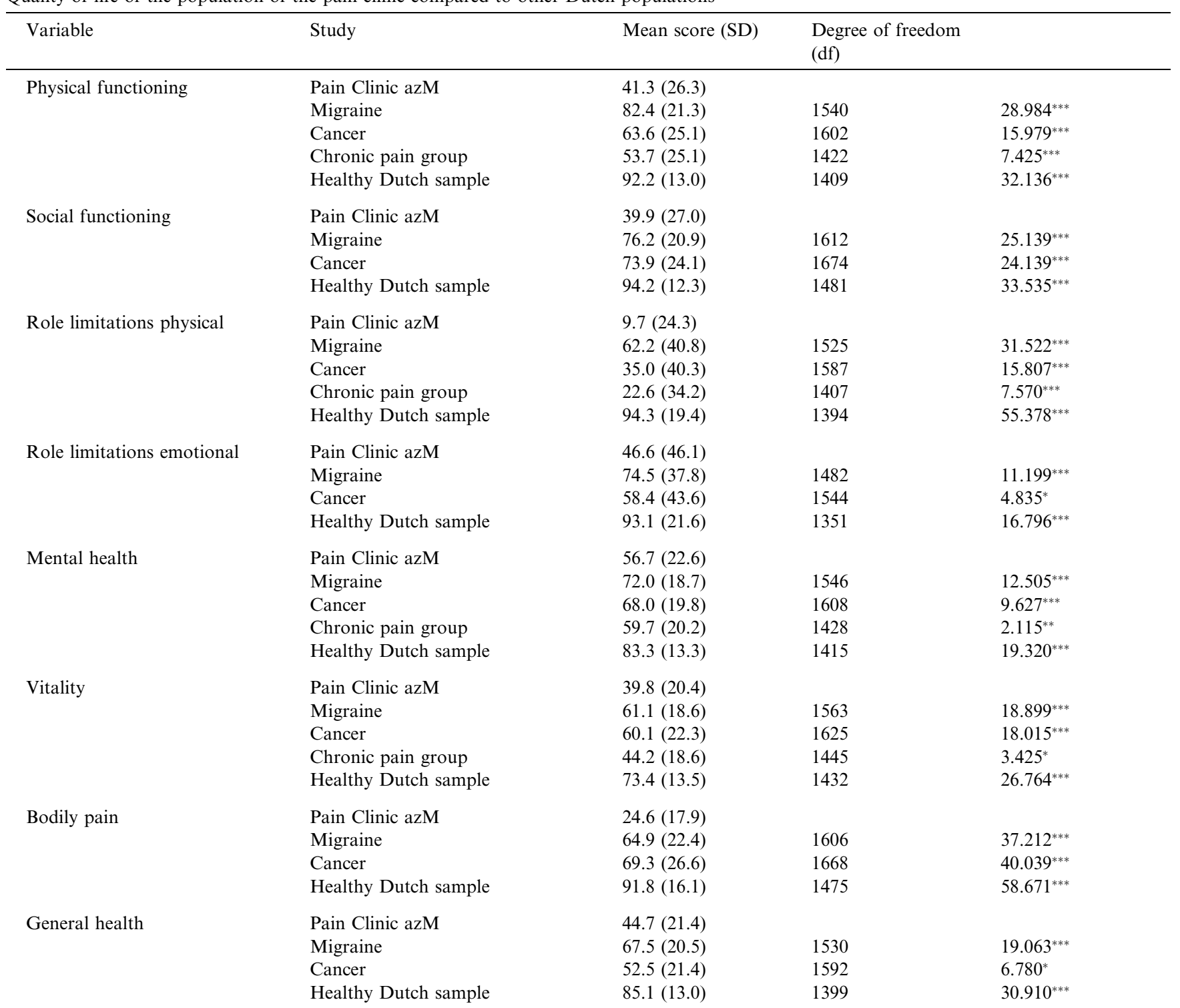

Migraine/cancer: Aaronson et al. (1998); chronic pain group: Verhaak et al. (2000) and a healthy Dutch sample: Van der Zee et al. (1996).

All differences are significant between the quality of life domains of the population of the pain clinic and all other populations.

${ }^{*} p<0.01$.

${ }_{* * *}^{* *} p<0.001$.

${ }^{* * *} p<0.0001$.

migraine/chronic headache and serious dermatological disorders (psoriasis and eczema)). The results showed that in particular physical functioning, role limitations physical and bodily pain were strongly affected by rheumatoid arthritis/other joint problems and back pain.

Independent of pain location and corrected for pain intensity, demographic variables and pain cognitions also influence quality of life. The gender differences found on physical functioning, role limitations physical, vitality, bodily pain and general health are consistent with other studies (Brazier et al., 1992; Severeijns et al., 2001; Sullivan and Karlsson, 1998). Women score lower than men, which imply that women are more disabled by pain than men. However, when other variables were taken into account in the regression analysis, gender no longer proved to be a significant predictor of quality of life. Females proved to be significantly more catastrophising than males in the present patient sample (i.e. 3.8 versus $3.6, p=0.001$ ) and it may be that their lower quality of life is due to their higher scores on catastrophising. Indeed, in step 1 of the regression analysis when catastrophising was not yet entered in the model, gender did come out as a significant predictor for most of the domains (physical functioning, role limitations physical, vitality, bodily pain and general health). 
Table 5

Summary of the hierarchical regression analyses for quality of life domains with step 1, demographic variables (age, gender and education) and pain intensity and step 2, the psychometric predictors (catastrophising, pain coping, internal pain control and external pain control) as independent variables

\begin{tabular}{|c|c|c|c|}
\hline Variable & Summary of the model & Predictors & \\
\hline Physical functioning & $\begin{array}{l}R^{2}=.25(F(7,998)=46.2 \\
p<0.0001)\end{array}$ & $\begin{array}{l}\text { Step 1: Gender } \\
\text { Age } \\
\text { Education } \\
\text { Total pain rating index } \\
\text { Step 2: Catastrophising } \\
\text { Pain coping } \\
\text { External pain control }\end{array}$ & $\begin{array}{l}\beta=0.05, p=0.07 \\
\beta=-0.20, p<0.0001 \\
\beta=0.19, p<0.0001 \\
\beta=-0.16, p<0.0001 \\
\beta=-0.32, p<0.0001 \\
\beta=-0.09, p=0.001 \\
\beta=0.08, p=0.01\end{array}$ \\
\hline Social functioning & $\begin{array}{l}R^{2}=.32(F(5,1098)=104.2 \\
p<0.0001)\end{array}$ & $\begin{array}{l}\text { Step 1: Gender } \\
\text { Age } \\
\text { Education } \\
\text { Total pain rating index } \\
\text { Step 2: Catastrophising }\end{array}$ & $\begin{array}{l}\beta=-0.02, p=0.36 \\
\beta=-0.06, p=0.03 \\
\beta=-0.02, p=0.40 \\
\beta=-0.15, p<0.0001 \\
\beta=-0.50, p<0.0001\end{array}$ \\
\hline Role limitations physical & $\begin{array}{l}R^{2}=.15(F(6,1023)=30.8 \\
p<0.0001)\end{array}$ & $\begin{array}{l}\text { Step 1: Gender } \\
\text { Age } \\
\text { Education } \\
\text { Total pain rating index } \\
\text { Step 2: Catastrophising } \\
\text { Pain coping }\end{array}$ & $\begin{array}{l}\beta=0.04, p=0.23 \\
\beta=0.02, p=0.60 \\
\beta=0.04, p=0.17 \\
\beta=-0.07, p=0.03 \\
\beta=-0.36, p<0.0001 \\
\beta=-0.10, p=0.001\end{array}$ \\
\hline Role limitations emotional & $\begin{array}{l}R^{2}=.27(F(7,953)=49.3 \\
p<0.0001)\end{array}$ & $\begin{array}{l}\text { Step 1: Gender } \\
\text { Age } \\
\text { Education } \\
\text { Total pain rating index } \\
\text { Step 2: Catastrophising } \\
\text { Internal pain control } \\
\text { External pain control }\end{array}$ & $\begin{array}{l}\beta=-0.02, p=0.57 \\
\beta=-0.05, p=0.06 \\
\beta=0.10, p=0.001 \\
\beta=-0.10, p=0.001 \\
\beta=-0.40, p<0.0001 \\
\beta=-0.17, p<0.0001 \\
\beta=-0.13, p<0.0001\end{array}$ \\
\hline Mental health & $\begin{array}{l}R^{2}=.46(F(8,997)=104.8 \\
p<0.0001)\end{array}$ & $\begin{array}{l}\text { Step 1: Gender } \\
\text { Age } \\
\text { Education } \\
\text { Total pain rating index } \\
\text { Step 2: Catastrophising } \\
\text { Pain coping } \\
\text { Internal pain control } \\
\text { External pain control }\end{array}$ & $\begin{array}{l}\beta=-0.03, p=0.30 \\
\beta=-0.10, p<0.0001 \\
\beta=0.06, p=0.01 \\
\beta=-0.13, p<0.0001 \\
\beta=-0.58, p<0.0001 \\
\beta=0.08, p=0.003 \\
\beta=-0.11, p<0.0001 \\
\beta=-0.06, p=0.02\end{array}$ \\
\hline Vitality & $\begin{array}{l}R^{2}=.37(F(5,1065)=125.5 \\
p<0.0001)\end{array}$ & $\begin{array}{l}\text { Step 1: Gender } \\
\text { Age } \\
\text { Education } \\
\text { Total pain rating index } \\
\text { Step 2: Catastrophising }\end{array}$ & $\begin{array}{l}\beta=0.04, p=0.12 \\
\beta=-0.01, p=0.73 \\
\beta=0.00, p=0.99 \\
\beta=-0.07, p=0.006 \\
\beta=-0.58, p<0.0001\end{array}$ \\
\hline Bodily pain & $\begin{array}{l}R^{2}=.31(F(6,1070)=79.6 \\
p<0.0001)\end{array}$ & $\begin{array}{l}\text { Step 1: Gender } \\
\text { Age } \\
\text { Education } \\
\text { Total pain rating index } \\
\text { Step 2: Catastrophising } \\
\text { Internal pain control }\end{array}$ & $\begin{array}{l}\beta=0.05, p=0.05 \\
\beta=-0.01, p=0.62 \\
\beta=0.05, p=0.08 \\
\beta=-0.20, p<0.0001 \\
\beta=-0.37, p<0.0001 \\
\beta=0.15, p<0.0001\end{array}$ \\
\hline General health & $\begin{array}{l}R^{2}=.34(F(7,1020)=73.5 \\
p<0.0001)\end{array}$ & $\begin{array}{l}\text { Step 1: Gender } \\
\text { Age } \\
\text { Education } \\
\text { Total pain rating index } \\
\text { Step 2: Catastrophising } \\
\text { Pain coping } \\
\text { Internal pain control }\end{array}$ & $\begin{array}{l}\beta=0.01, p=0.78 \\
\beta=-0.01, p=0.64 \\
\beta=0.05, p=0.07 \\
\beta=-0.06, p=0.02 \\
\beta=-0.56, p<0.0001 \\
\beta=0.09, p=0.004 \\
\beta=-0.13, p<0.0001\end{array}$ \\
\hline
\end{tabular}

The second aim of the present study was the search for predictors of quality of life. The results from this study show that pain catastrophising is by far the most prom- inent predictor of social functioning, mental health, vitality and general health. The association between catastrophising and the physical aspects of quality of life 
(physical functioning, role limitations physical and bodily pain) is less prominent, but is still relatively strong and stronger than the association of these domains of quality of life with pain intensity. These results agree with findings of Severeijns et al. (2002) and extend previous findings in low back pain patients (Crombez et al., 1999a; Severeijns et al., 2002, 2001; Vlaeyen et al., 1995b). Vlaeyen et al. (1995b) have introduced the fear of movement/ injury model, which states that disability is related to fear of movement and catastrophising. As fear of movement seems to be of importance in particular for patients with musculo-skeletal pain and we studied a group of heterogeneous pain patients, we have focused on catastrophising in this study. Our findings are in accordance with Severeijns et al. (2002). The authors analysed data of a Dutch survey of the prevalence and course of musculoskeletal complaints. They examined five patient groups with different musculoskeletal pain localisations and one patient group without pain. They found that pain catastrophising is best associated with the social and psychological aspects of quality of life (social functioning, mental health, vitality and general health).

The results in this study are based on catastrophising scored with the PCCL. In previous studies catastrophising has been measured mostly with either the pain catastrophising scale (PCS) or the catastrophising subscale of the coping strategies questionnaire (CSQ) (Crombez et al., 1999a; Severeijns et al., 2002, 2001; Vlaeyen et al., 1995b). The present study included the PCS as well. There was a high correlation between the PCCL and PCS (pearsons $r=.64, p<0.0001$ ). Vlaeyen et al. (1990) also reported a strong correlation $(r=.73)$ between the PCS and the PCL (Pain Cognition List), the questionnaire from which the PCCL was developed. Moreover, when regression analyses were performed with the PCS scores instead of the PCCL catastrophising scale, similar results as the ones reported above were found. While for the PCCL there are no comparative data, the scores on the PCS show that in comparison to previous studies, including back pain patients, our population scored very high on catastrophising (PCS total mean score $=31.0$ ). Others found lower total mean scores of PCS, i.e. Van den Hout et al. (2001) found a total mean score of 16.8 for low back pain patients; Van Damme et al. (2002) found a total mean score of 22.0 for chronic low back pain patients and 25.5 for fibromyalgia patients and Crombez et al. (2002) found a total mean score of 23.6 for back pain patients. Thus, the low quality of life in a multi-disciplinary university pain population that we found in this study relative to other studies with chronic pain patients may originate from the higher level of catstrophising in our patient population. We hypothesize that the university pain clinic population is a highly catastrophising group, with a high medical consumption, which explains the relatively low scores on all quality of life domains.
From a medical point of view the results of the present study are of essential importance. An adequate screening method, by concentrating on psychological predictors before treatment in order to identify patients with psychological suffering, can give a better guarantee that the most efficient treatment strategy is selected, either medical and/or cognitive behavioural. Recently, Holdcroft and Power (2003) reviewed literature concerning management of pain in multidisciplinary pain clinics and noticed that there is more willingness to consider the psychosocial factors, when medical treatment and/or physical interventions are failing. Increasingly there is evidence for a major effect of cognitive behavioural therapy. Pain catastrophising as a predictor of the psychological burden of illness may imply that first cognitive behavioural treatment is offered, after which medical treatment can be more effective or is perhaps no longer needed. This leads to the hypothesis that a treatment focused on decreasing the level of catastrophising, may increase the effect of medical treatment. Studies showing that pain catastrophising is associated with the outcome of invasive pain treatments, support this hypothesis (Samwel et al., 2000).

There are a number of limitations of the present study that should be take account of. First, because of the cross-sectional study design, causal inferences cannot be made. Second, the used mail-out methodology can contain several kinds of biases. However, the strength of this study is the very high response rate, because returning the screening questionnaire was a condition for a first medical visit. Finally, the description of the five pain clusters is based on self-reports. A fairly global classification was made, based on the answer the patient has given on the question: "which pain complaints do you have?' Future studies with pain groups based on medical diagnosis should be carried out, especially to find out whether the associations found in this study apply in these pain complaints as well.

\section{Acknowledgements}

The authors thank Rudy Severeijns, at the department of Medical Psychology of the University Hospital Maastricht for his help with the initial construction of the questionnaire and Chris Lawrence, at the department of anaesthesiology, of the University Hospital Maastricht, for valuable comments on the manuscript.

\section{References}

Aaronson NK, Acquadro C, Alonso J, Apolone G, Bucquet D, Bullinger $\mathrm{M}$, et al. International Quality of Life Assessment (IQOLA) Project. Quality of Life Research: An International Journal of Quality of Life Aspects of Treatment, Care and Rehabilitation 1992;1(5):349-51. 
Aaronson NK, Muller M, Cohen PD, Essink-Bot ML, Fekkes M, Sanderman $\mathrm{R}$, et al. Translation, validation, and norming of the Dutch language version of the SF-36 Health Survey in community and chronic disease populations. $\mathbf{J}$ Clin Epidemiol 1998;51(11):1055-68.

Becker N, Bondegaard Thomsen A, Olsen AK, Sjogren P, Bech P, Eriksen J. Pain epidemiology and health related quality of life in chronic non-malignant pain patients referred to a Danish multidisciplinary pain center. Pain 1997;73(3):393-400.

Brazier JE, Harper R, Jones NM, O'Cathain A, Thomas KJ, Usherwood T, et al. Validating the SF-36 health survey questionnaire: new outcome measure for primary care. BMJ 1992;305(6846):160-4.

Buer N, Linton SJ. Fear-avoidance beliefs and catastrophizing: occurrence and risk factor in back pain and ADL in the general population. Pain 2002;99(3):485-91.

Crombez G, Eccleston C, Baeyens F, Eelen P. When somatic information threatens, catastrophic thinking enhances attentional interference. Pain 1998;75(2-3):187-98.

Crombez G, Eccleston C, Baeyens F, van Houdenhove B, van den Broeck A. Attention to chronic pain is dependent upon painrelated fear. J Psychosom Res 1999a;47(5):403-10.

Crombez G, Eccleston C, Vlaeyen JW, Vansteenwegen D, Lysens R, Eelen P. Exposure to physical movements in low back pain patients: restricted effects of generalization. Health Psychology Official Journal of the Division of Health Psychology, American Psychological Association 2002;21(6):573-8.

Crombez G, Vlaeyen JW, Heuts PH, Lysens R. Pain-related fear is more disabling than pain itself: evidence on the role of painrelated fear in chronic back pain disability. Pain 1999b;80(12):329-39.

Crombez G, Vlaeyen JWS. The pain catastrophizing scale. Unpublished Dutch/Flemish translation, 1996.

Engstrom D. Cognitive behavioral therapy methods in chronic pain treatments. In: Bonica JJ, editor. Advances in pain research and therapy. New York: Raven Press; 1983. p. 829-38.

Essink Bot ML, Krabbe PF, Bonsel GJ, Aaronson NK. An empirical comparison of four generic health status measures. The Nottingham Health Profile, the Medical Outcomes Study 36-item ShortForm Health Survey, the COOP/WONCA charts, and the EuroQol instrument. Med Care 1997;35:522-37.

Gureje O, Von Korff M, Simon GE, Gater R. Persistent pain and wellbeing: A World Health Organization Study in Primary Care. JAMA 1998;280(2):147-51.

Holdcroft A, Power I. Recent developments: management of pain. BMJ Clin Res Ed 2003;326(7390):635-9.

Hout van den JHC, Vlaeyen JWS, Heuts PHTG, Sillen WJT, Willen AJEHL. Functional disability in nonspecific low back pain: the role of pain-related fear and problem-solving skills. Int $\mathbf{J}$ Behav Med 2001;8(2):134-48.

Keefe FJ, Brown GK, Wallston KA, Caldwell DS. Coping with rheumatoid arthritis pain: catastrophizing as a maladaptive strategy. Pain 1989;37(1):51-6.

Keefe FJ, Lefebvre JC, Egert JR, Affleck G, Sullivan MJ, Caldwell DS. The relationship of gender to pain, pain behavior, and disability in osteoarthritis patients: the role of catastrophizing. Pain 2000;87(3):325-34.

Kempen GI, Ormel J, Brilman EI, Relyveld J. Adaptive responses among Dutch elderly: the impact of eight chronic medical conditions on health-related quality of life. Am J Public Health 1997;87(1):38-44.

Kuile ter MM, Linssen ACG, Spinhoven P. The development of the multidimensional locus of pain control questionnaire (MLPC), factor Structure, reliability and validity. J Psychopathol Behav Assess 1993;15:387-404.

Lethem J, Slade PD, Troup JDG, Bentley G. Outline of a fearavoidance model of exaggerated pain perception. Behav Res Ther $1983 ; 21: 401-8$.
Linton SJ. Early identification and intervention in the prevention of musculoskeletal pain. Am J Ind Med 2002;41(5):433-42.

Morley S, Eccleston C, Williams A. Systematic review and metaanalysis of randomized controlled trials of cognitive behaviour therapy and behaviour therapy for chronic pain in adults, excluding headache. Pain 1999;80(1-2):1-13.

Romano JM, Turner JA. Chronic pain and depression: does the evidence support a relationship. Psychol Bull 1985;97(1):18-34.

Samwel H, Slappendel R, Crul BJ, Voerman VF. Psychological predictors of the effectiveness of radiofrequency lesioning of the cervical spinal dorsal ganglion (RF-DRG). Eur $\mathrm{J}$ Pain 2000;4(2):149-55.

Schlenk EA, Erlen JA, Dunbar Jacob J, McDowell J, Engberg S, Sereika SM, et al. Health-related quality of life in chronic disorders: a comparison across studies using the MOS SF-36. Quality of Life Research: An International Journal of Quality of Life Aspects of Treatment, Care and Rehabilitation 1998;7(1):57-65.

Severeijns R, van den Hout MA, Vlaeyen JW, Picavet HS. Pain catastrophizing and general health status in a large Dutch community sample. Pain 2002;99(1-2):367-76.

Severeijns R, Vlaeyen JW, van den Hout MA, Weber WE. Pain catastrophizing predicts pain intensity, disability, and psychological distress independent of the level of physical impairment. Clin J Pain 2001;17(2):165-72.

Sieben JM, Vlaeyen JW, Tuerlinckx S, Portegijs PJ. Pain-related fear in acute low back pain: the first two weeks of a new episode. Eur J Pain 2002;6(3):229-37.

Spinhoven P, Kuile ter MM, Linssen ACG. Coping met Pijn Vragenlijst (CPV) handleiding/experimentele versie. Swets \& Zeitlinger: Lisse; 1994

Stewart AL, Greenfield S, Hays RD, Wells K, Rogers WH, Berry SD, et al. Functional status and well-being of patients with chronic conditions. Results from the Medical Outcomes Study. JAMA 1989;262(7):907-13.

Stomp-van den Berg SGM, Vlaeyen JWS, Kuile ter MM, Spinhoven $P$, Breukelen van $G$, Kole-Snijders AMJ. Meetinstrumenten chronische pijn: deel 2 Pijn Coping en Cognitie Lijst (PCCL). Maastricht, Pijn Kennis Centrum, AZM, 2001.

Sullivan M, Karlsson J. The Swedish SF-36 Health Survey III. Evaluation of criterion-based validity: results from normative population. J Clin Epidemiol 1998;51(11):1105-13.

Sullivan MD, Loeser JD. The diagnosis of disability. Treating and rating disability in a pain clinic. Arch Int Med 1992;152(9):1829-35.

Sullivan MJL, Bishop SR, Pivik J. The pain catastrophizing scale: development and validation. Psychol Assess 1995;7(4):524-32.

Turk DC, Okifuji A. Perception of traumatic onset, compensation status, and physical findings: impact on pain severity, emotional distress, and disability in chronic pain patients. J Behav Med 1996;19(5):435-53.

Van Damme S, Crombez G, Bijttebier P, Goubert L, Van Houdenhove B. A confirmatory factor analysis of the pain catastrophizing scale: invariant factor structure across clinical and non-clinical populations. Pain 2002;96(3):319-24.

Van Damme S, Crombez G, Vlaeyen JWS, Goubert L, Van den Broeck A, Van Houdenhove B. De pain catastrophizing scale: psychometrische karakteristieken en normering. Gedragstherapie 2000;3:211-22.

Van der Zee K, Sanderman R, Heyink J. De psychometrische kwaliteiten van de MOS 36-item Short Form Health Survey (SF36) in een Nederlandse populatie. T Soc Gez 1993;71:183-91.

Van der Zee K, Sanderman R, Heyink JW, Haes dH. Psychometric qualities of the Rand 36-item health survey 1.0: a multidimensional measure of general health status. Int $\mathbf{J}$ Behav Med 1996;3:104-22.

Verhaak PFM, Kerssens JJ, Bensing JM, Sorbi MJ, Peters ML, Kruise DA. Medical help-seeking by different types of chronic pain patients. Psychol Health 2000;15:771-86. 
Verkes J, Vanderiet K, Vertommen H, Van der Kloot WA, Van der Meij J. De MPQ-DLV: een standaard Nederlandstalige versie van de Mc Gill Pain Questionnaire voor Belgie en Nederland. In: Van der Kloot WA, editor. De MPQ-DLV: een standaard Nederlandstalige versie van de Mc Gill Pain Questionnaire Achtergronden en handleiding. Swets \& Zeitlinger: Lisse; 1989. p. $59-67$.

Vlaeyen JW, Kole-Snijders AM, Boeren RG, van Eek H. Fear of movement/(re)injury in chronic low back pain and its relation to behavioral performance. Pain 1995a;62(3):363-72.
Vlaeyen JW, Linton SJ. Fear-avoidance and its consequences in chronic musculoskeletal pain: a state of the art. Pain 2000;85(3):317-32.

Vlaeyen JWS, Geurts SM, Kole-Snijders AMJ, Schuerman JA, Groenman NH, Eek van H. What do chronic pain patients think of their pain. Towards a pain cognition questionnaire. Br J Clin Psychol 1990;28:383-94.

Vlaeyen JWS, Kole Snijders AMJ, Rotteveel AM, Ruesink R. The role of fear of movement/(re)injury in pain disability. J Occup Rehab $1995 \mathrm{~b} ; 5: 235-52$. 